\title{
Introduktion: Viden og styring
}

\author{
Anne Mette Møller, ph.d.-stipendiat, Institut for Statskundskab, \\ Københavns Universitet \\ Signe Blaabjerg Christoffersen, ph.d., konsulent, KL's ledelsessekretariat
}

Dette temanummer af Politik stiller skarpt på samspillet mellem viden og styring i velfærdsstaten - et tema, der både er eviggyldigt og påtrængende aktuelt. På stadig flere områder lanceres indikatorer evalueringssystemer i bestræbelserne på at opnå en mere sikker viden og dermed et bedre grundlag for beslutninger og prioriteringer $i$ en kontekst præget af begrænsede ressourcer. Inden for store velfærdsområder som sundhed, uddannelse, beskæftigelses- og socialområdet har der længe været massivt fokus på evidensbaseret politik og praksis - tæt fulgt af ophedede debatter om betydningen af 'evidens', og hvilken rolle evidens kan og bør spille i styrings- og beslutningsprocesser. Evidens, oftest forstået som viden om resultater og effekter, ses i høj grad som et nødvendigt grundlag for den kloge styring. Men samtidig er idealer om resultatbaseret styring og evidensbaseret praksis jævnligt genstand for kritik. Der stilles løbende spørgsmål ved, om idealerne kan indfries $i$ en offentlig kontekst præget af komplekse styringskæder og behovet for faglige skøn, eller om det er nødvendigt med helt andre tilgange til styringen af de fagprofessionelle. Ofte får diskussionerne karakter af sammenstød mellem grundlæggende forskellige vidensidealer, logikker, behov, interesser og værdier.

Én ting er sikkert: Udviklingen i en politisk ledet offentlig sektor er ikke drevet af rationalitet alene. Ofte er der stor uenighed om både mål og midler, og derfor er politiske valg og prioriteringer langt fra blot teknokratiske spørgsmål om blot at finde den mest velegnede eller virkningsfulde metode til at opnå et givent mål. I forlængelse heraf er det sjældent entydigt, hvad der tæller som relevant og gyldig viden i forskellige sammenhænge. Ikke desto mindre fortsætter bestræbelserne på at tilskrive systematisk produceret viden en større rolle. Der findes - særligt blandt vidensproducenterne selv en ukuelig og optimistisk tiltro til, at den rette viden, produceret under de rette betingelser, kan føre til mere oplyste og dermed bedre beslutninger, hvad enten det gælder nye policy-initiativer eller en konkret indsats over for en konkret borger. Også i forskningsverdenen finder vi dermed $\mathrm{i}$ disse år en fornyet interesse for, hvordan viden fra forskning, evalueringer og andre kilder anvendes og omsættes i politik og praksis. Nogle ser evidensbaseret viden som et afgørende alternativ til erfarings- og praksisbaseret viden, mens andre advokerer for, at evidensbaseret viden er 'betydningsløs' i sig selv: Det er 
blot data eller information, som først får karakter af egentlig viden, når det fortolkes $\mathrm{i}$ lyset af erfaring, ekspertise og værdier - i relation til den konkrete anvendelseskontekst.

Der findes en hastigt voksende forskningslitteratur om, hvordan og hvorvidt det er muligt at 'overføre' eller 'omsætte' forskningsbaseret viden til politisk og praktisk handlen (Contandriopoulos et al. 2010; Graham et al. 2006; Greenhalgh \& Wieringa 2011; Grimshaw et al. 2012; Nutley et al. 2007; Schwandt 2015; Ward et al. 2009). Store dele af denne litteratur udspringer fra sundhedsområdet og bestræbelserne på at fremme en mere evidensbaseret praksis i denne kontekst. Derfor forekommer den ofte afkoblet fra de indsigter, som den mere samfundsvidenskabeligt og politologisk orienterede forskning byder på. Kigger man til samfundsvidenskaben og videnskabssociologien, finder man således en række tilgange, der på flere måder udfordrer de mange modeller og kogebogslignende opskrifter og anbefalinger, som præger litteraturen om 'knowledge translation', som det ofte kaldes i den internationale litteratur. Studier inden for den videnskabssociologiske tradition har længe stillet spørgsmål ved den videnskabelige videns 'naturlige' autoritet ved at undersøge, hvordan forskellige former for viden bliver til, og med hvilke virkemidler forskellige vidensbidrag opnår legitimitet og anerkendelse som fakta (f.eks. Latour and Woolgar 1979). I et mere praksisnært perspektiv er forholdet mellem viden og handling et velkendt tema i litteraturen om professioner og professionsudøvelse (f.eks. Abbott 1988; Greenhalgh 2010; Schön 1983). Ligeledes findes der en stor litteratur, der undersøger, hvordan forskellige normer, idealer og organisationsideer - som f.eks. evidensbaseret praksis eller resultatbaseret styring - sætter sig igennem i organisationer og organisationsfelter, 'oversættes' til praksis og med tiden (måske) bliver institutionaliseret i mere eller mindre genkendelige former (f.eks. Czarniawska \& Sevón 1996; DiMaggio \& Powell 1983; Meyer \& Rowan 1977; Røvik 2007). Pointen her er, at viden, koncepter og modeller aldrig forbliver uforandrede, men altid fortolkes og omformes i mødet med en konkret kontekst. Det gælder således også, når resultatdata skal fortolkes, og evidensbaserede koncepter skal omsættes til praksis.

Ud fra et samfundsvidenskabeligt perspektiv er det dermed ikke alene relevant at udvikle og afprøve konkrete måder at understøtte omsætningen af 'viden' eller 'evidens' til politisk eller praktisk handlen, men også at spørge til selve idealerne for denne omsætning og deres præmisser: Hvilke former for viden anses for at være relevante $i$ et styrings- såvel som et praksisperspektiv? Under hvilke forudsætninger og betingelser kan vi producere og anvende denne viden? Hvilke dynamikker udspiller sig i forsøgene herpå? På hvilke måder spiller viden fra forskning, evalueringer og administrative data sammen med politiske holdninger, værdier, etiske hensyn og udøvelsen af professionel dømmekraft? Hvornår giver det egentlig mening at sige, at en beslutning er baseret på viden eller evidens? Bidragene til dette temanummer er alle forankret i en samfundsvidenskabelig tilgang med rødder i politologi, sociologi og forvaltningsforskning og trækker på forskellig vis på ovennævnte forskningstraditioner. Dermed forholder forfatterne sig gennemgående kritisk til flere af de grundlæggende antagelser, som kendetegner den stadigt voksende produktion af data/information/viden med henblik på styring. Men samtidig ser de også kritisk på kritikken. Fælles for dem alle er, at de først og fremmest 
har et pragmatisk og undersøgende ærinde. De advokerer således ikke for eller imod bestemte idealmodeller for produktion af viden til styring og beslutningstagning, men forsøger derimod både kritisk og konstruktivt at afdække nogle af de virkninger og dynamikker, som forskellige idealer afstedkommer i praksis.

Til sammen bidrager artiklerne til at kaste lys over nogle af de ovenstående spørgsmål for herigennem at udvide vores vante perspektiver på relationerne mellem viden og styring. Skal man pege på en fællesnævner, må det være det grundlæggende udgangspunkt, at forsknings- og evalueringsbaseret viden og evidens ikke er objektive størrelser, som i egen ret finder vej til beslutningsprocesser. Der er altid tale om, at nogen gør noget for, at bestemte vidensbidrag (ikke) kommer til at spille en rolle. Data gøres (ir)relevante. Evidensbaseret viden og praksis gøres (il)legitim. Sundhedsøkonomiske beregninger gøres (u)forsvarlige. Eftersom der altid er en flerhed af aktører med hver deres perspektiver og interesser involveret, er processerne sjældent uden omkostninger og konflikter. Ved at udfolde nogle af de dynamikker, der udspiller sig i det danske velfærdslandskab i disse år, håber vi med dette temanummer at bidrage til en mere nuanceret debat om relationerne mellem viden og styring.

Præsentation af de fem artikler

Temanummerets første artikel af Hjalte Meilvang introducerer og diskuterer begrebet 'kontroversiel relevans'. Det centrale argument i artiklen er, at tal - eksempelvis indikatorer - grundlæggende er konstruerede og dermed politiske størrelser, som først for alvor bliver relevante, når de bruges til noget. Brug øger imidlertid risikoen for kontroverser: Tal der virker, virker ofte på en måde, som nogen er imod. I artiklen udfoldes argumentet om tallenes kontroversielle relevans gennem en analyse af debatten om de nationale tests i den danske folkeskole og forskellige aktørers forsøg på at gøre testresultaterne relevante.

I diskussioner om evidensbaseret praksis i folkeskolen og på socialområdet fremhæves sundhedsområdet ofte som et eksempel til efterfølgelse. Også inden for sundhedsområdet kæmper man imidlertid med at få den nyeste viden fra forskningen til at gøre en forskel i praksis, hvad den omfangsrige litteratur på dette område vidner om. Samtidig er der også her utallige etiske overvejelser og en flerhed af holdninger og værdier involveret $\mathrm{i}$ den politiske stillingtagen til, hvilken rolle videnskabeligt funderet viden bør spille i beslutningsprocesser. Det kommer tydeligt til udtryk i Sarah Wadmanns artikel om viden, værdi og ekspertise i den danske debat om lægemiddelprioritering. Wadmann viser, hvordan det nye Medicinråd i dag skal evaluere behandlingsomkostninger ved nye behandlinger - men uden at gøre brug af gængse sundhedsøkonomske metoder til at sammenholde effekt og omkostninger. Som følge af debatten er de sundhedsøkonomiske metoder, som anvendes i flere andre lande, blevet fravalgt til fordel for situationsbetinget (politisk) dømmekraft. 
Den professionelle dømmekraft er til gengæld udfordret på andre områder. Dét er emnet for Marie Østergaard Møller og Vibeke Normann Andersens artikel om statsligt forankret resultatbaseret styring af lokal kernevelfærd. Artiklen er skrevet på baggrund af forfatternes omfattende review af resultatbaseret styring, som gav anledning til en langvarig offentlig debat i foråret 2016. I denne artikel forsøger forfatterne at forklare, hvad der mere præcist sker, når resultatbaseret statsstyring møder velfærdsprofessionelle med et stort professionelt skøn i regelanvendelsen over for borgerne. Konklusionen er, at den indbyggede logik i resultatbaseret styring 'kortslutter' den professionelle dømmekraft. Forfatterne peger på, at netop denne dynamik kan være en væsentlig årsag til manglende positive effekter af resultatbaseret styring.

Evidensbaseret praksis er sammen med resultatbaseret styring en af tidens helt store styringstrends. Anne Mette Møller undersøger i sin artikel, hvordan evidensdagsordenen har udfoldet sig på socialområdet, herunder hvordan forskellige politiske aktører fortolker idealet om en evidensbaseret praksis. Artiklen viser, at forståelserne over tid har ændret sig, og at der i dag kan identificeres to forskellige perspektiver, som ikke nødvendigvis er gensidigt udelukkende. Det ene perspektiv fremhæver den lokale og organisatorisk forankrede refleksion over data til udvikling af praksis, mens det andet perspektiv er centralt forankret og har data-drevet styring som bærende vision. Begge visioner indebærer et skifte fra en vægtning af global forskningsbaseret evidens og implementering af evidensbaserede metoder til en vægtning af lokalt produceret evidens, som både omfatter evalueringsresultater og administrative data. Uenighederne handler i dag om, i hvilket omfang og med hvilket formål disse data skal produceres. I det først perspektiv anses den fagprofessionelle erfaring og dømmekraft som nødvendig for at kunne omsætte data til reflekteret handling - mens den i det andet perspektiv snarere ses som en potentielt problematisk 'bias', der skal kontrolleres. Her ses således en tydelig kobling til Møller og Andersens diskussion af vilkårene for det fagprofessionelle skøn.

Evidensdagsordenen er ligeledes udgangspunktet for temanummerets sidste artikel af Niels Borch Rasmussen, der bringer os tilbage til folkeskolen, hvor vi startede. Her genfinder vi, ligesom på socialområdet, koblingen mellem evidensbaseret praksis og faglig refleksion. Rasmussen viser, hvordan en kommunal skoleforvaltning legitimerer arbejdet med at indføre metoden 'læringsmålstyret undervisning' med henvisning til evidens. Ønsket er at etablere en refleksiv praksis, hvor lærerne har et professionelt ansvar for løbende at udvikle deres didaktiske metoder i overensstemmelse med den nyeste viden om, hvad der virker. Rasmussen argumenterer dermed for, at refleksion og professionel dømmekraft ikke nødvendigvis udgrænses af idealer om evidensbaseret praksis - i den pågældende case bevirker evidensdagsordenen snarere, at den faglige refleksion forankres organisatorisk og dermed sættes i system, frem for at være et individuelt anliggende.

Til sammen illustrerer de fem artikler på fornem vis, hvad der sker, når forskellige idealer om viden og styring støder sammen i konkrete handlingsrum: Når den forskningsbaserede viden møder de fagprofessionelles hverdag, og når forskerens og den fagprofessionelles viden møder den politiske virkelighed. Både de videnskabelige 
og fagprofessionelle idealer har svære vilkår i den politiske verden. Derfor står den politiske uenighed også centralt $\mathrm{i}$ alle artiklerne og vidner om, at relationerne mellem viden og styring i sidste ende netop er af politisk karakter.

\section{Litteratur}

Abbott, A. D. (1988). The system of professions: an essay on the division of expert labor. University of Chicago Press: Chicago.

Contandriopoulos, D., Lemire, M., Denis, J.-L. and Tremblay, É. (2010). Knowledge exchange processes in organizations and policy arenas: a narrative systematic review of the literature. Milbank Quarterly, vol. 88, pp. 444-483.

Czarniawska, B. and Sevón, G. (eds.). (1996). Translating Organizational Change (de Gruyter Studies in Organization 56). Berlin; New York: Walter de Gruyter.

DiMaggio, P. J. and Powell, W. W. (1983). The Iron Cage Revisited: Institutional Isomorphism and Collective Rationality in Organizational Fields. American Sociological Review, vol. 48, pp. 147-160.

Graham, I. D., Logan, J., Harrison, M. B., Straus, S. E., Tetroe, J., Caswell, W. and Robinson, N. (2006), Lost in knowledge translation: Time for a map?. Journal of Continuing Education in the Health Professions, vol. 26, pp. 13-24.

Greenhalgh, T. (2010). What is this knowledge that we seek to "exchange"?. Milbank Quarterly, vol. 88, pp. 492-499.

Greenhalgh, T. and Wieringa, S. (2011). Is it time to drop the "knowledge translation" metaphor? A critical literature review. JRSM, vol. 104, pp. 501-509.

Grimshaw, J. M., Eccles, M. P., Lavis, J. N., Hill, S., J and Squires, J. E. (2012). Knowledge translation of research findings. Implement Sci, vol. 7 (50).

Latour, B. and Woolgar, S. (1979). Laboratory life: the construction of scientific facts. Princeton, N.J: Princeton University Press.

Meyer, J. W. and Rowan, B. (1977). Institutionalized Organizations: Formal Structure as Myth and Ceremony. American Journal of Sociology, vol. 83(1), pp. 340363.

Nutley, S., Walter, I. and Davies, H. T. O. (2007). Using Evidence: How research can inform public services. Bristol: Policy Press.

Røvik, K. A. (2007). Trender og translasjoner, ideer som former det 21. århundrets organisasjon. Oslo: Universitetsforlaget.

Schön, D. A. (1983) The reflective practitioner: how professionals think in action. New York: Basic Books.

Schwandt, T. A. (2015). Iagttagelser af anvendelse af videnskabelig evidens i politik og praksis. Økonomi \& Politik, vol. 88, pp. 5-11. 
Ward, V., House, A. and Hamer, S. (2009). Knowledge brokering: the missing link in the evidence to action chain?. Evidence \& Policy: A Journal of Research, Debate and Practice, vol. 5, pp. 267-279. 